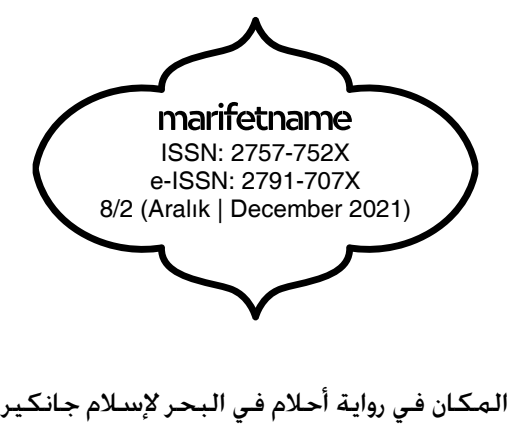

The Space Phenomenon in Aslam Jankır's Novel "Ahlâm fi'l-Bahr (Dreams in the Sea)"

Aslam Jankır'ın "Ahlâm fi'l-Bahr (Denizdeki Düşler)" Adlı Romanındaki Mekân Olgusu

\title{
Halid Halid
}

Dr. Öğr. Üyesi, Siirt Üniversitesi İlahiyat Fakültesi, Arap Dili ve Belagatı Anabilim Dalı, Siirt/Türkiye Assist. Prof,, Siirt University Faculty of Theology, Department of Arabic Language and Rhetoric, Siirt/Turkey siamndo1@hotmail.com | orcid.org/ 0000-0001-6930-2523

DOI: $10.47425 /$ marifetname.vi.969969

Makale Bilgisi | Article Information

Makale Türü | Article Type: Araştırma Makalesi | Research Article

Geliş Tarihi | Received: 12 Temmuz / July 2021

Kabul Tarihi | Accepted: 14 Aralık / December 2021

Yayın Tarihi | Published: 30 Aralık / December 2021

\section{Attf $\mid$ Cite as}

Halid, Halid. “Aslam Jankır'ın 'Ahlâm fi'l-Bahr (Denizdeki Düşler)' Adlı Romanındaki Mekân Olgusu [The Space Phenomenon in Aslam Jankır's Novel Ahlâm fi'l-Bahr (Dreams in the Sea)]”. Marifetname. 8/2 (Aralık /2021), s. 591-606.

\section{İntihal | Plagiarism}

Bu makale, iThenticate aracılı̆̆gyla taranmış ve intihal tespit edilmemiştir. This article, has been scanned by iThenticate and no plagiarism has been detected.

\section{Copyright $(9$}

Published by Siirt University Faculty of Divinity. Siirt/Turkey. web: https://dergipark.org.tr/tr/pub/marifetname mail: sifdergisi@gmail.com 


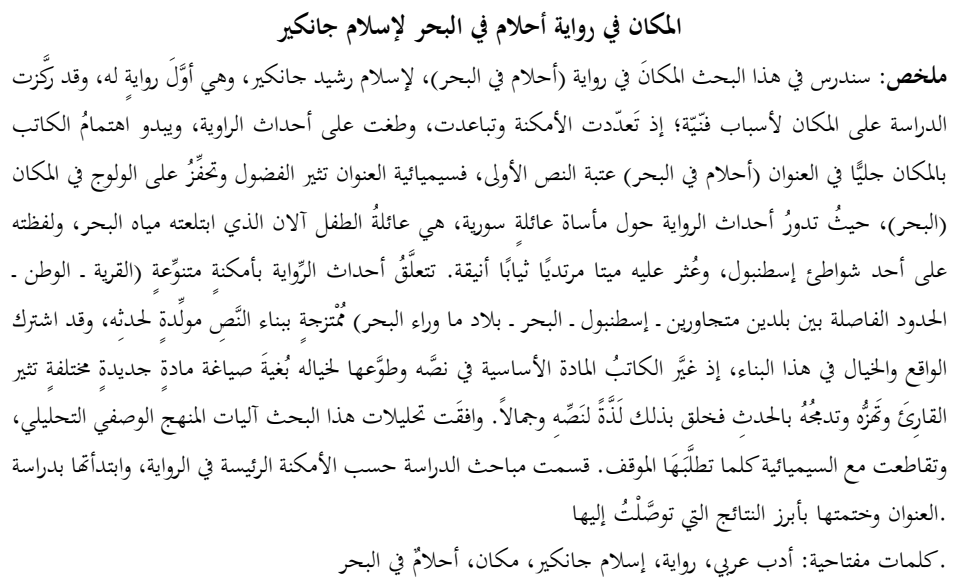

\section{The Space Phenomenon in Aslam Jankur's Novel “Ạ̣lâm fi'l-Bạ̣r (Dreams in the Sea)"}

Abstract: This research examines the space phenomenon in the novel 'Dreams in the Sea', which is accepted as the first novel of Aslam Reşit Jankır. The study has focused on the phenomenon of «space» and has chosen this topic for many technical reasons. Because there are many and far places in the novel, and the phenomenon of «space» dominates the events in the work. The author's emphasis on space is clearly observed from the first stage of the work represented by the title. The semiotics of the title arouses the curiosity of entering the place (sea) where the drama of a Syrian family takes place. It is the family of the boy who became the subject of the agenda by being found drowned in his elegant dresses on the coast of Istanbul. The events in the novel are productively linked to many places as they are fused with the structure of the text and are up-to-date: Village-homeland-the borders separating two neighboring countries-Istanbul-sea-overseas countries. 'Real' and 'imagination' are intertwined within this structure. Because the author has changed the main element in his text and has given it to the imagination so as to work on a new subject that excites and trembles the reader and drags them into the event. The author thus created a flavor and beauty for his text. The analyzes of this research are compatible with the mechanics of the analytical descriptive method and intersect with semiotics to the required extent.

Keywords: Arabic Literature, Novel, Aslam Jankır, Place, Dreams at Sea 


\section{Aslam Jankır'ın “Ạ̣lâm f'1-Baḥr (Denizdeki Düşler)” Adlı Romanındaki Mekân Olgusu}

Öz: Bu araştırma, İslam Reşit Çankır'nın ilk romanı kabul edilen Denizdeki Düsler adlı romandaki 'mekân' olgusunu incelemektedir. İnceleme, 'mekân' olgusuna yönelmiş ve pek çok teknik nedenden ötürü bu konuyu seçmiştir. Çünkü romanda, çok sayıda ve birbirinden uzak mekânlar yer almaktadır. 'Mekân' olgusu romandaki olaylarda baskın faktör olarak dikkati çekmektedir. Yazarın romanına "Ehlam fi'l-Babr" adını vermesi ilk aşamadan itibaren mekâna önem verdiğini açıkça görmekteyiz. Başlığın semiyotiği (göstergebilimi), Suriyeli bir ailenin dramının geçtiği mekâna (denize) girme merakı uyandırmaktadır. Aile, İstanbul sahilinde zarif elbiseleriyle boğulmuş bir hâlde bulunarak gündem olmuş bir çocuğun ailesidir. Romandaki olaylar, metnin yapısı ile kaynaşmış ve güncel olması itibariyle de üretken bir surette pek çok yerle/mekânla bağlantılıdır: Köy-vatan-iki komşu ülkeyi ayıran sınırlar-İstanbul-deniz-deniz ötesi ülkeler. 'Gerçek' ve 'bayal, bu yapıda iç içe geçmiştir. Çünkü yazar, metnindeki ana unsuru değiştirmiş ve okuyucuyu heyecanlandıran, titreten ve onu olayın içine sürükleyen yeni bir konu işleme arzusuyla onu hayalin emrine vermiştir. Yazar böylece, zevkli ve güzel bir roman ortaya koymuştur. $\mathrm{Bu}$ araştırmanın analizleri, analistik tanımlama yöntemin mekaniği ile uyumlu olup, durumun gerektirdiği ölçüde semiyotikle (göstergebilimle) kesişmektedir. Romandaki ana mekânlara göre kısımlara ayırdım ve ulaştı̆̆ım en bariz sonuçları zikrederek tamamladım.

Anahtar Kelimeler: Arap Edebiyatı, Roman, Aslam Jankır, Mekân, Denizdeki Düşler.

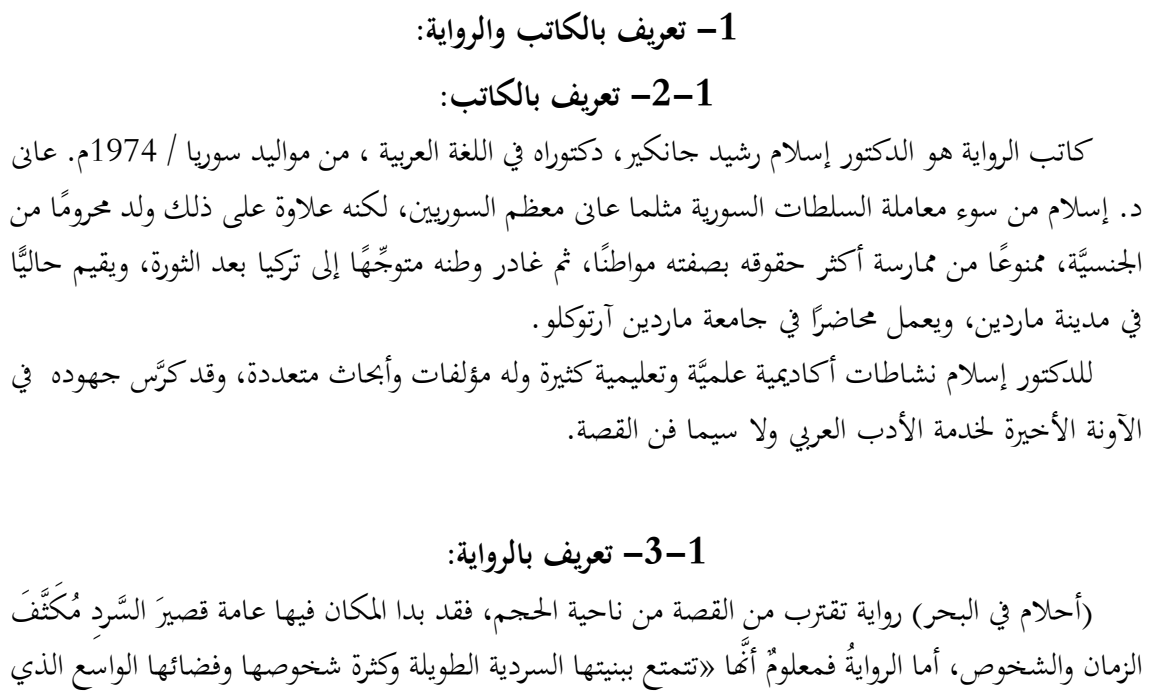


تتحرك فيه. ويبدو المكان فيها غنيّا واضحَ المعالم يتفاعل مع الشخوص بوضوح《1. ولكن لم تخضع الرواية

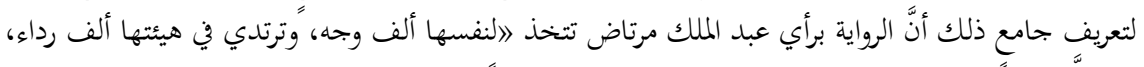

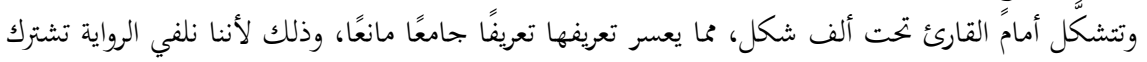

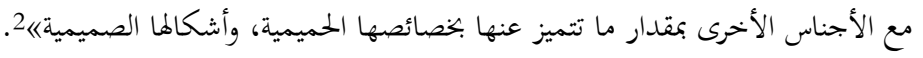

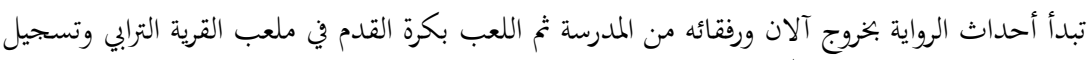

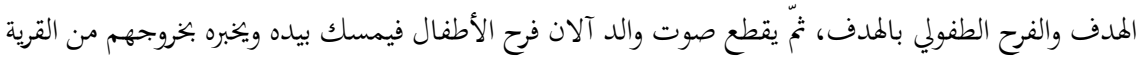
والهجرة إلى بلاد ما وراء البحار.

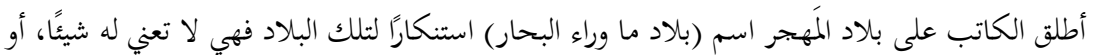

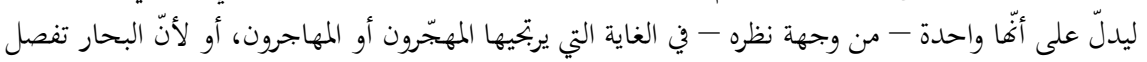

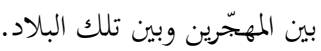

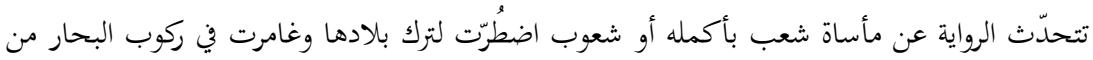

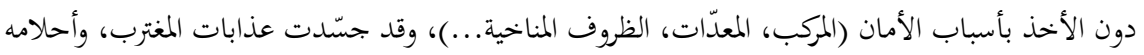

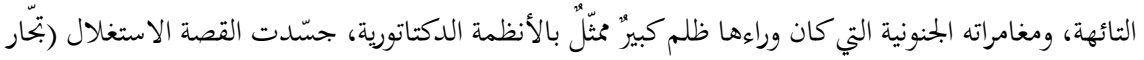

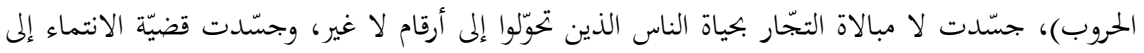

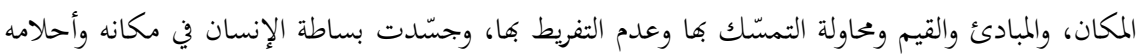
التي راودته للرجوع والإعمار. هاية الرواية أشبه بالفانتازيا فالموج يغلب القارب، ويغرق الإبه الركاب ويغرق آلان من جهة وهو ملقًى على

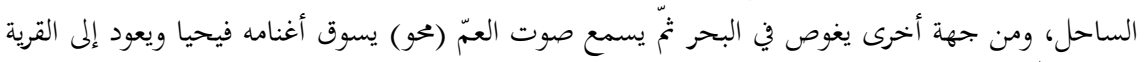
مع أمّه وركّاب المركب الذين أحبّهم من أجل إعمار القرية وتحقيق الأحلام فيها.

\section{2- تعريف المكان لغة واصطلاحًا:}

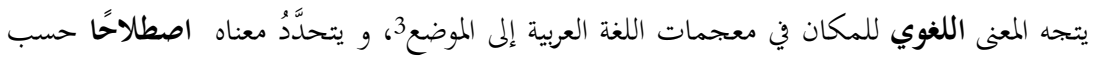

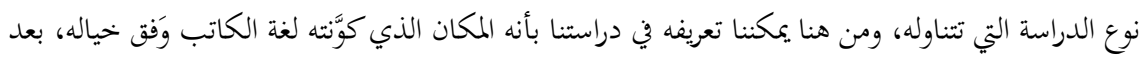

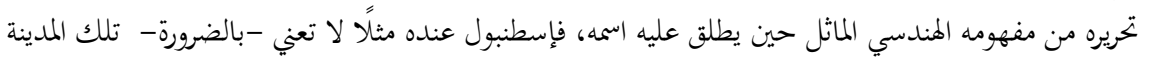

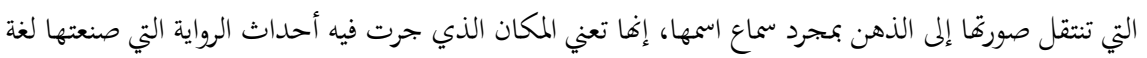

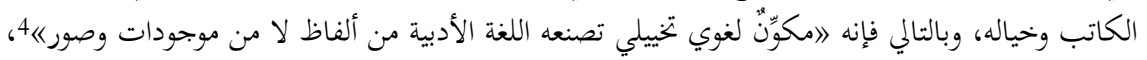

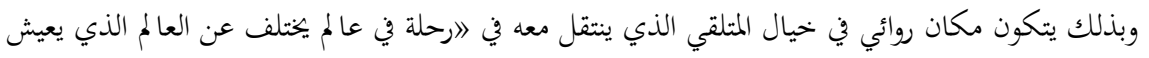

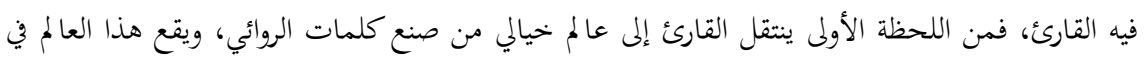

\footnotetext{
1 آبادي، محبوبة محمدي محمد، جماليات المكان في قصص سعيد حورانية، وزارة الثقافة الهيئة العامة السورية للكتاب، دمشق، 2011 م،

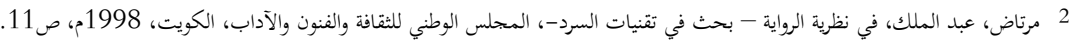

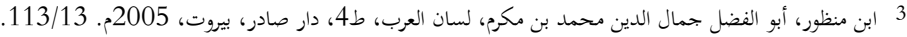

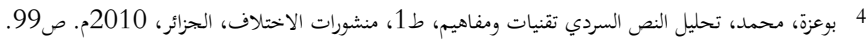




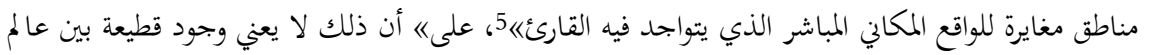

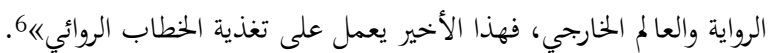

\section{3- سردية المكان في الرواية:}

من المعلوم عند الشكلانيين الروس أن القصَّ أو السرد هو الوسيلة التي توصل القصة للمتلقي (القارئ،

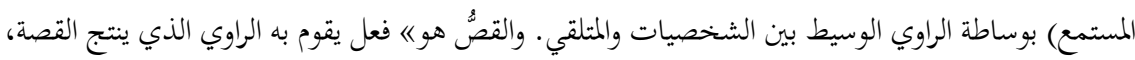

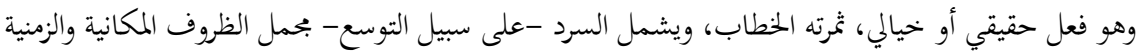

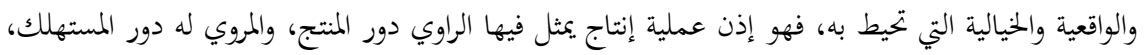

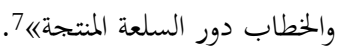

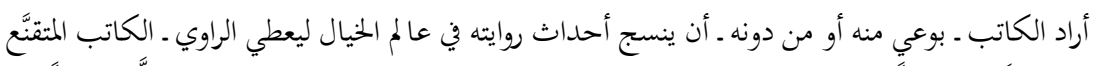

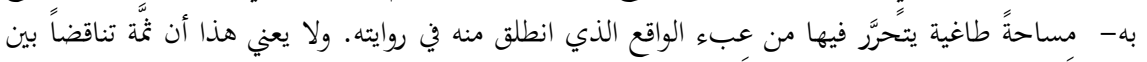

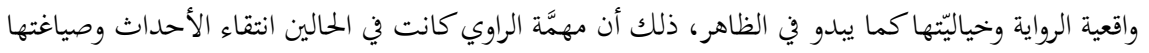

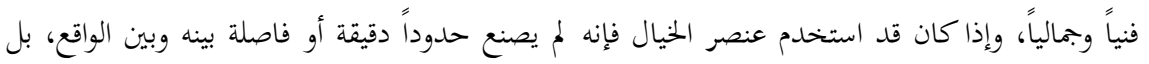

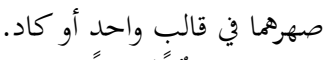

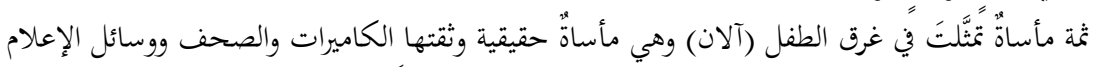

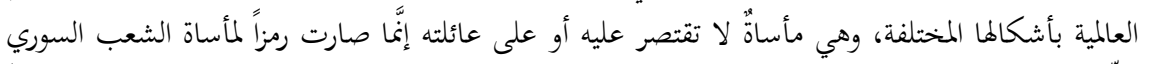

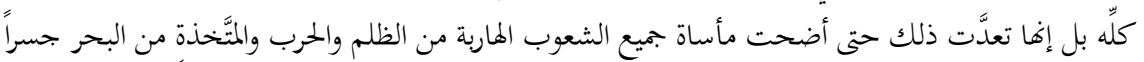

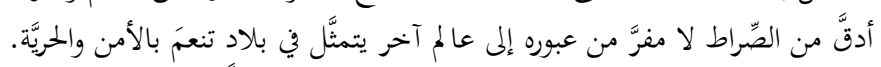

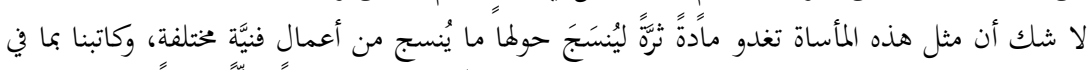

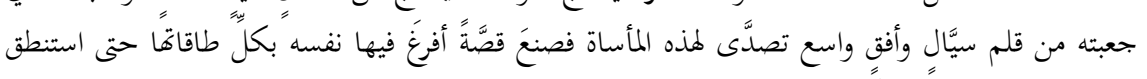

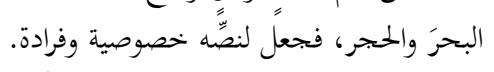

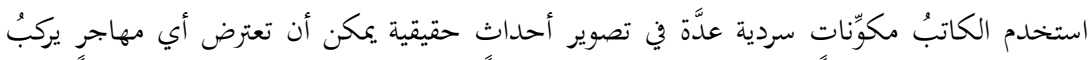

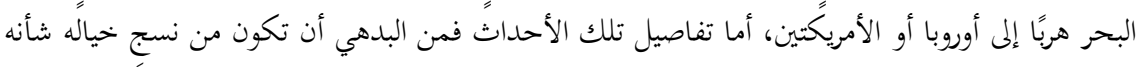

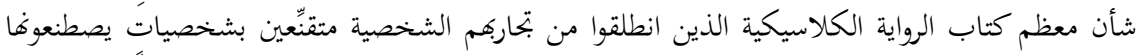

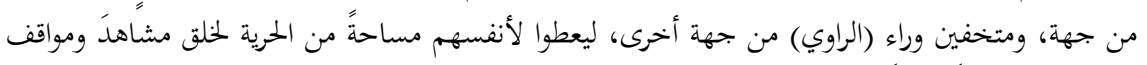
تجعل النصَّ شائقاً ومتمعاً.

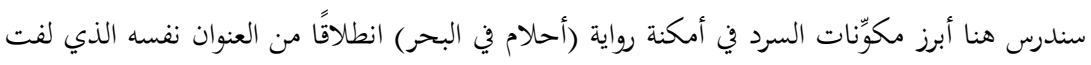

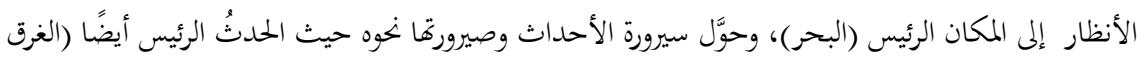

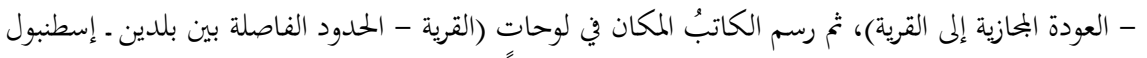

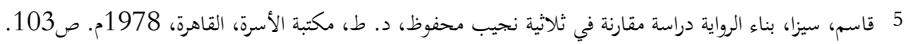

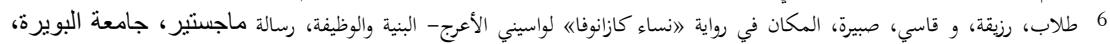

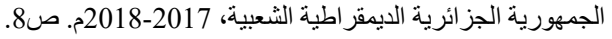

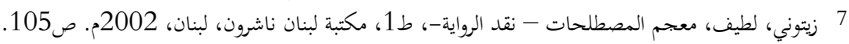


ـ البحر)، وهي الأمكنة الرئيسة في روايته التي كانت مسرحًا لأحداثها المتسلسلة إذ اتَّع في رسمهما تسلسلًا

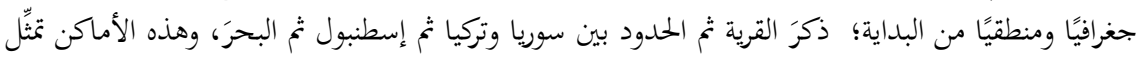

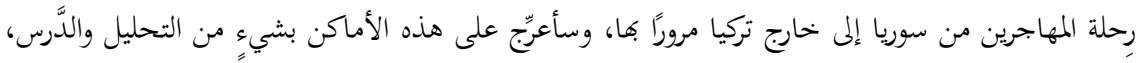

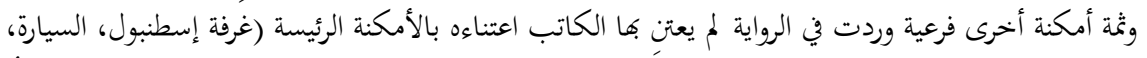

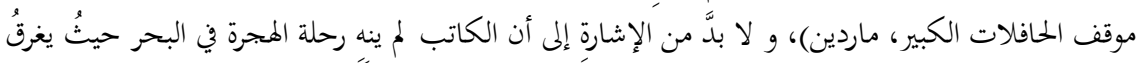

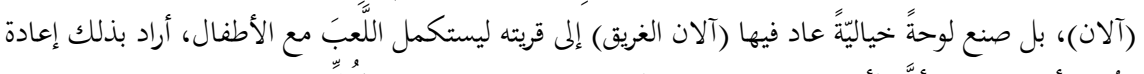
الرُوّح لأبناء الوطن وأنَّ المأساة ستنتهي وتعود الحياة إلى القرية التي ترمز إلى كُلِّ سوريا.

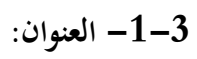

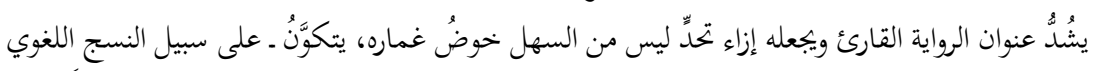

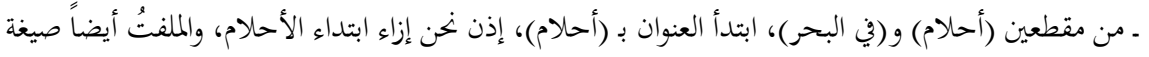

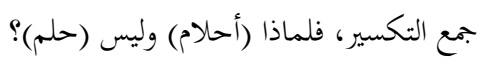

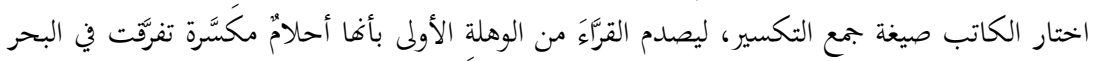

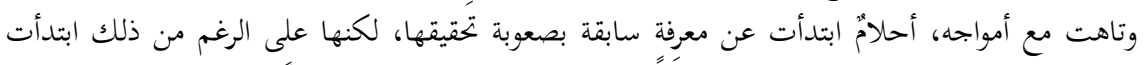

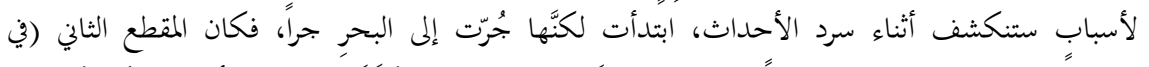

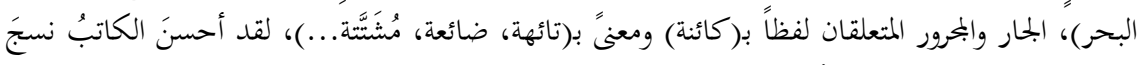

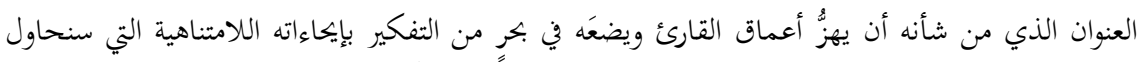

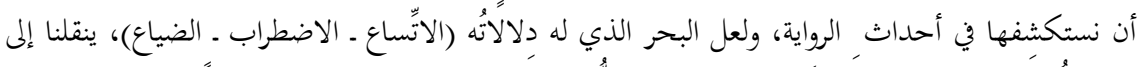

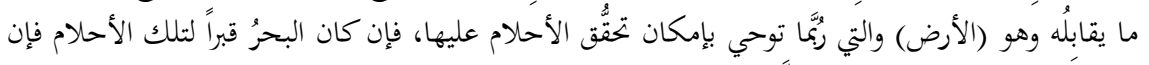

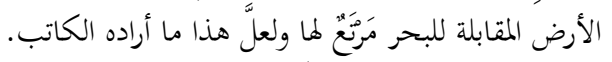

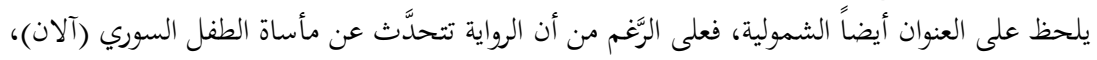

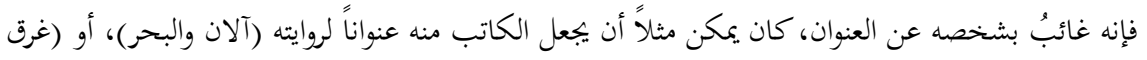

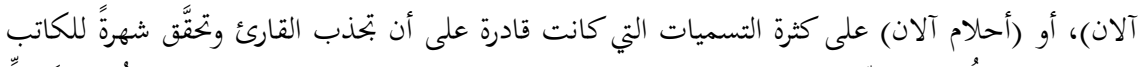

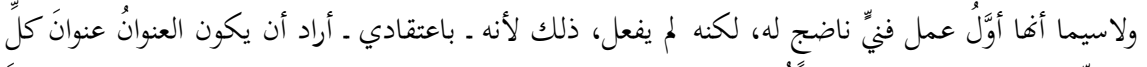

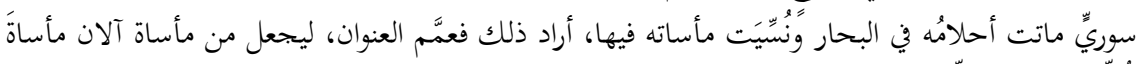

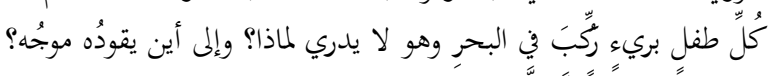

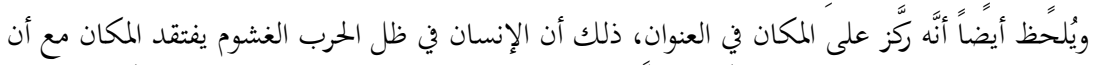

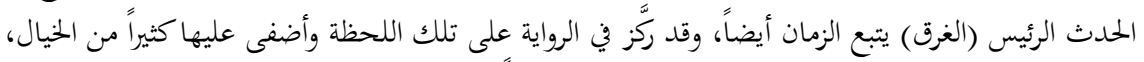

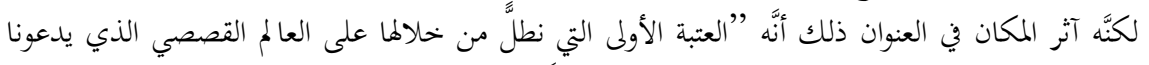

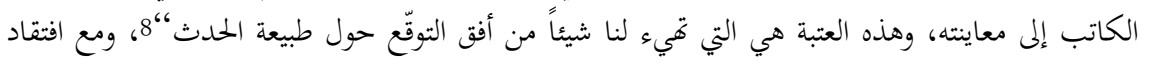
المكان يغدو الغرق نتيجة طبيعية. 
لكل ما سبق ما كان لنا أن نتجاوزَ عتبة النَّصِّ الأولى المتمثَّلة في عنوانه، الذي سيبقى هدفاً لكثيرٍ من

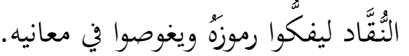

$$
\text { 3-3 }
$$

أغرقَ الكاتبُ في الوصف هنا، وصفَ طبيعة القرية، ووصفَ الأعمال اليومية لأهلها، وفي الحقيقة يبدو

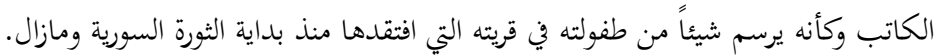

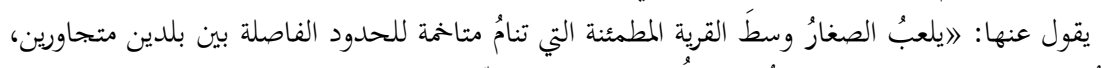

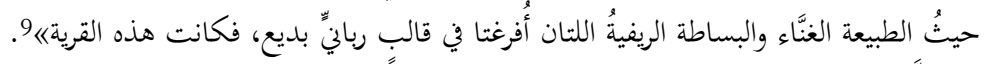

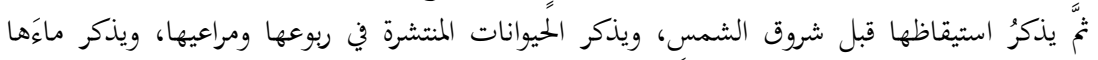

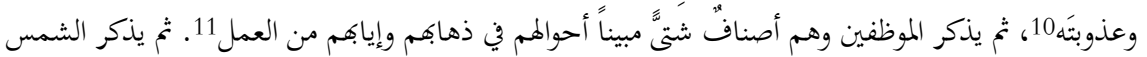

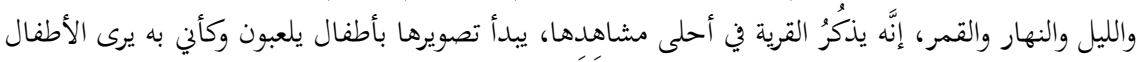

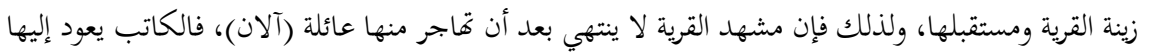

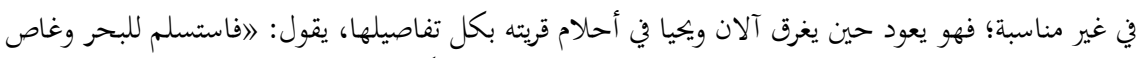

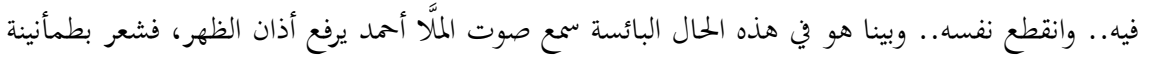

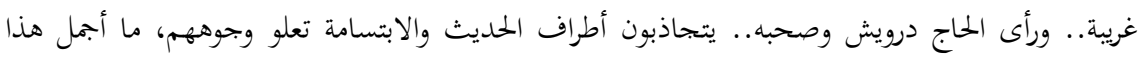

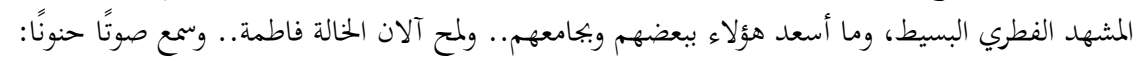
هررز، هررر.

$$
\text { إنه صوت العم (محو) وهو على رأس قطيع الغنم... }
$$

ما أجمل قريتي!

$$
\text { أبي، أمي، لقد عدنا إلى قريتنا بسرعة. }
$$

هنا في القرية سنصنع مستقبلنا يا أبي. سنعمر قريتنا يا أبي عندما أكبر أنا وشيركو وأحمد وكل فيتا أصدقائي.

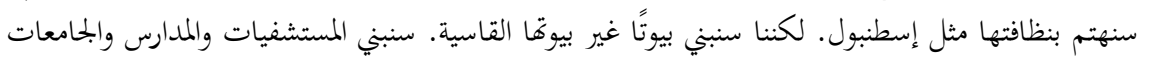

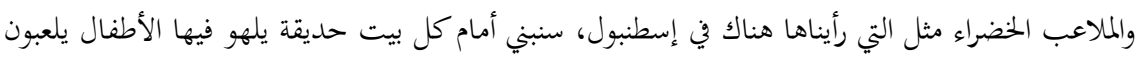

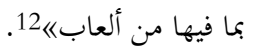

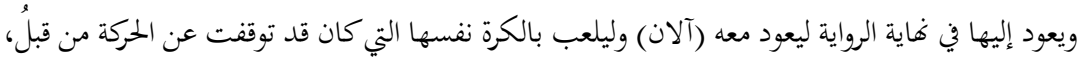

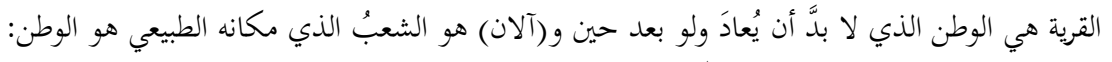

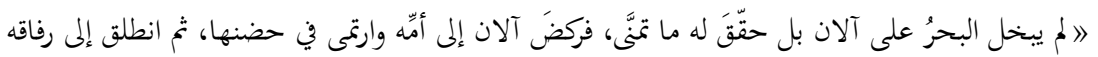

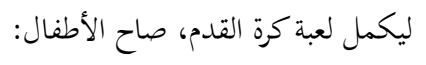

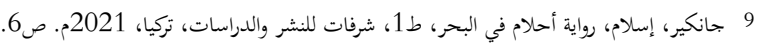

10

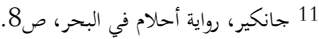

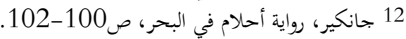




$$
\begin{aligned}
& \text { هيييبيه: } \\
& \text { لقد عاد. } \\
& \text { والله قد عاد. } \\
& \text { آلان لم يرحل يا أصدقائي } \\
& \text { ولن يرحل يرل ياصل } \\
& \text { نعم. } \\
& \text { آلان لن يترك القرية. }
\end{aligned}
$$

أحاط الرفاق بآلان يحضنونه ويقبّلونه حتى الكرة الجامدة تحركت واستقبلت قدميه الصغيرتين تقبّلهما،

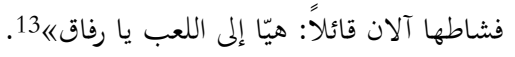

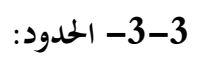

هنا حيثُ الأسلاك الشائكة التي تفصل بلدين متجاورين متجانسين في كثير من الأشياء، لا

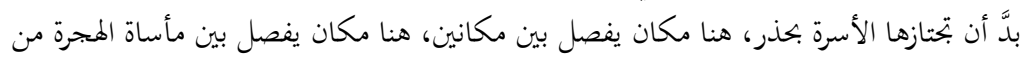

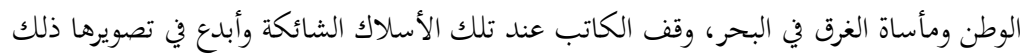

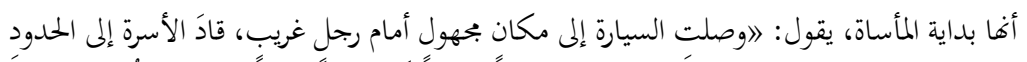

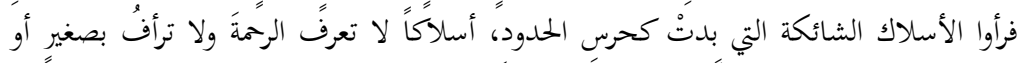

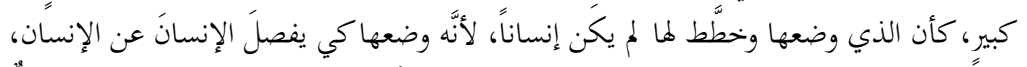

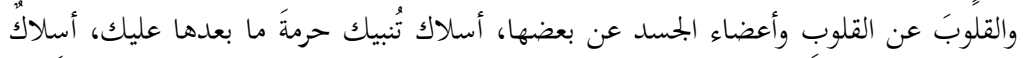

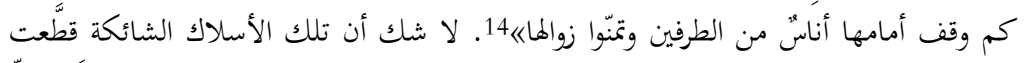

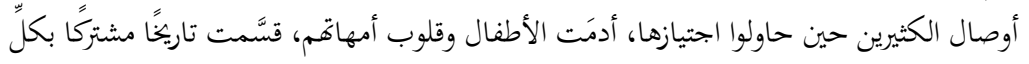
تفاصيله بين بلدين كانا من قبل واحدًا.

$$
\text { 3-3- - إسطنبول: }
$$

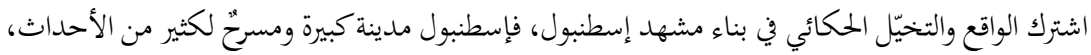

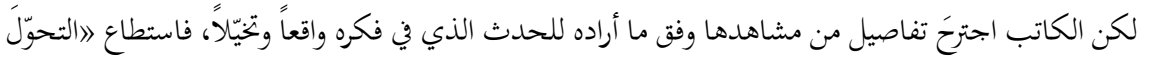

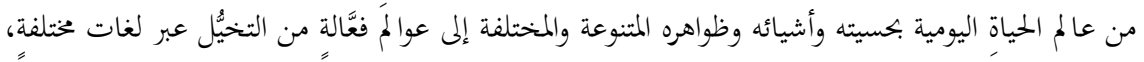

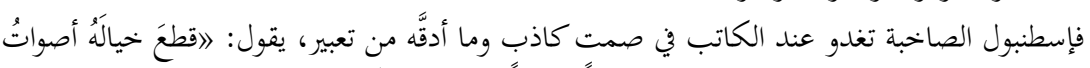

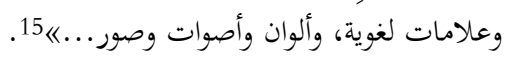

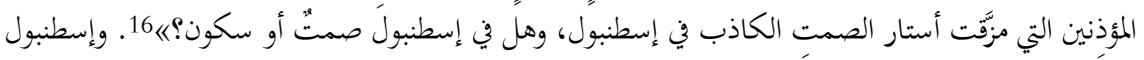


الشهيرة بجمالها والتي يقصدها الناس من كلٍ حدب وصوب اختار منها الكاتب ما وظَّفه في مقارنته ببلده

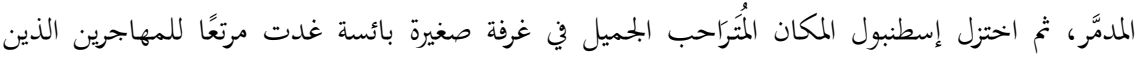

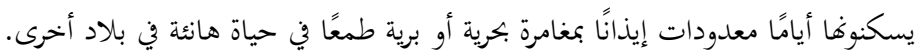

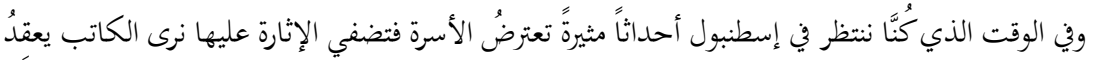

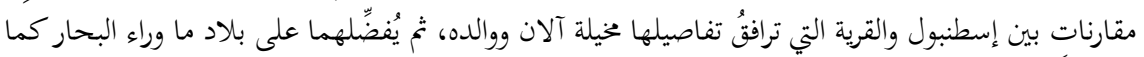

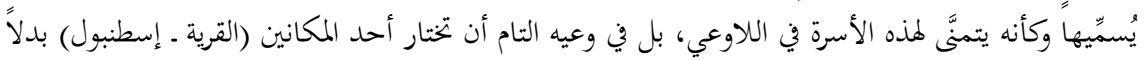

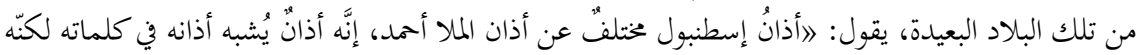

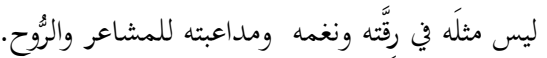

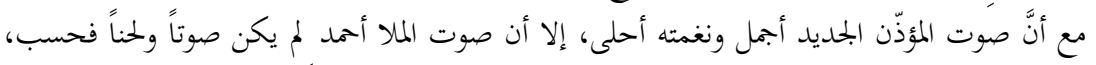

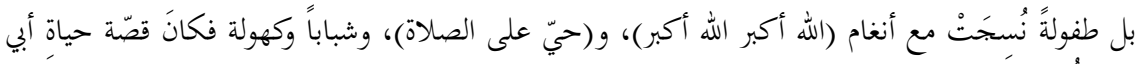

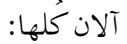
سبحان الله حتى الأذانُ مختلفُ في هذه الباد لكن لا أذانَ في بلاد ما وراء البحار، فلأستمتع هذذا الأذان

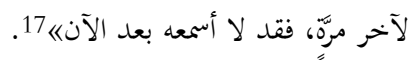

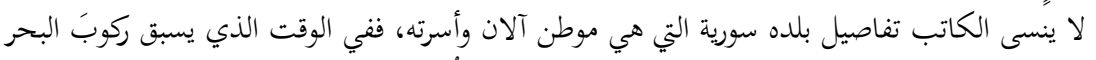

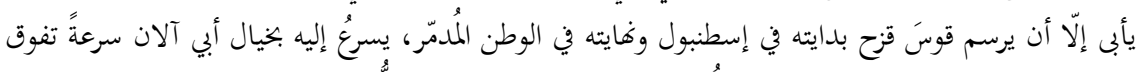

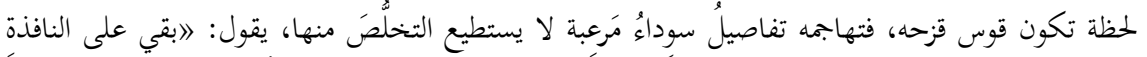

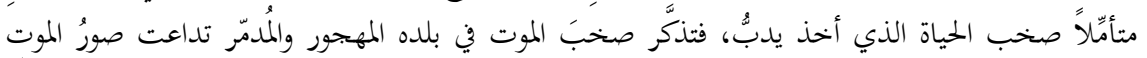

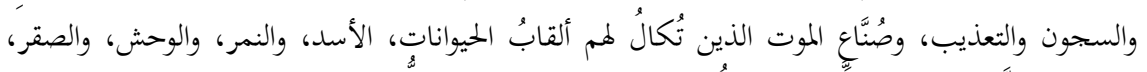

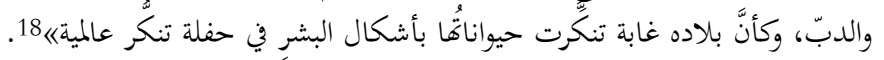

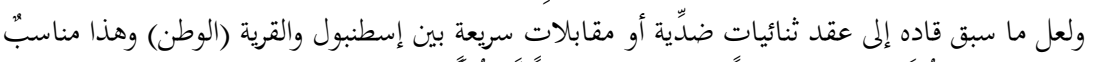

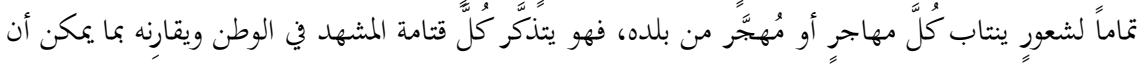

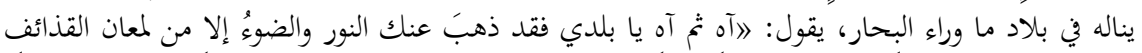

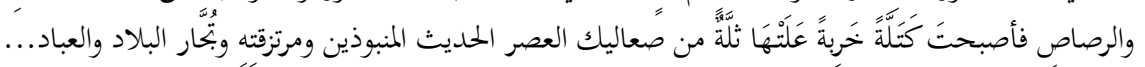

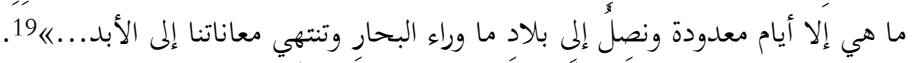

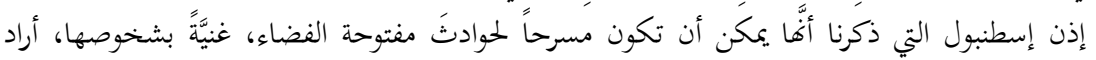

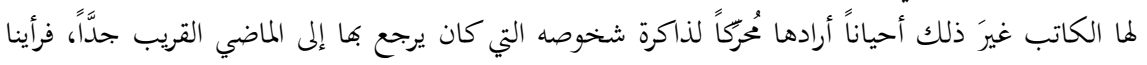

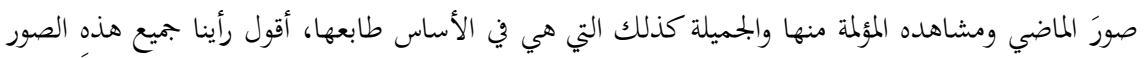

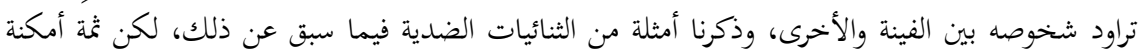


مرتبطة بذاكرة الشخوص تصنعها الذاكرة وتمنحها دلالة مكانية وجغرافية تُدلُّ على الصور المتخيلة للمكان الحقيقي من بن. منها تلك الذاكرة التي تعود بأبي آلان إلى كُلٍّ مشاهد القرية (الوطن) فيتذكر المائدة المستديرة في البيتِ

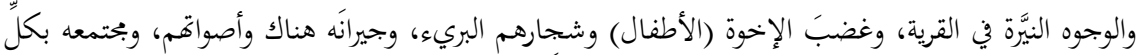

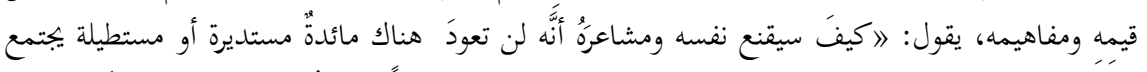

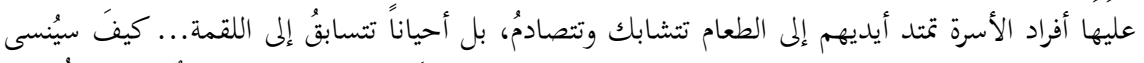

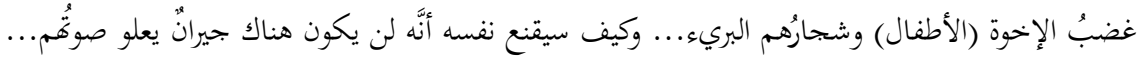

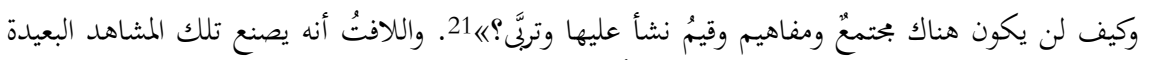

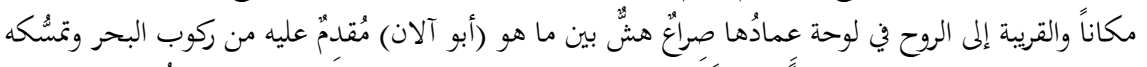

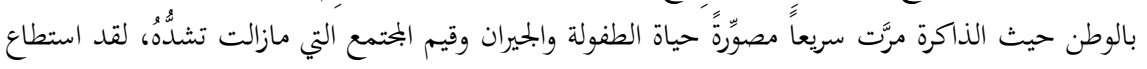

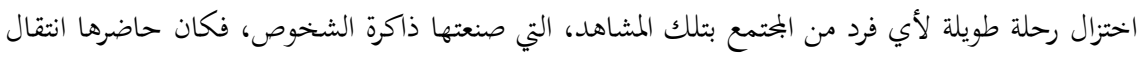

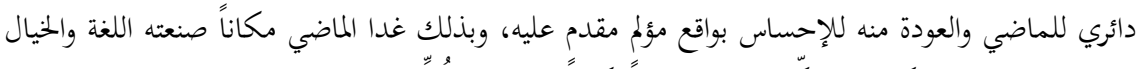

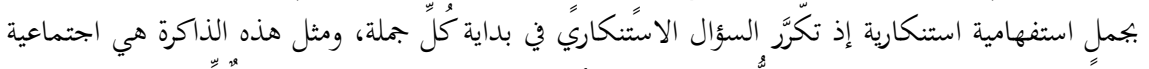

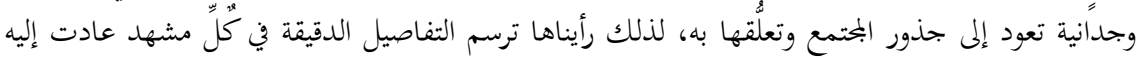

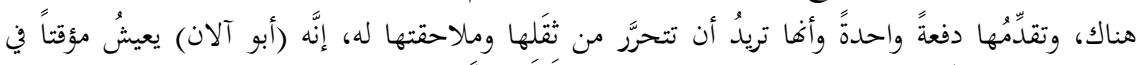

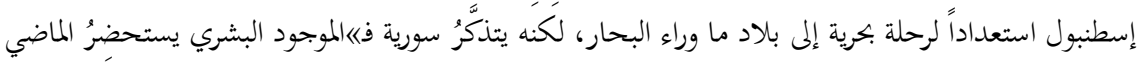
بداخله بواسطة الذاكرة في الحاضری22.

$$
\text { : 5-3 }
$$

كانت صورة البحر سلبية في الرواية، فقد تحوَّل من مكان خدميٍٍ ومصدر للرزق ومقصد سياحي -كما

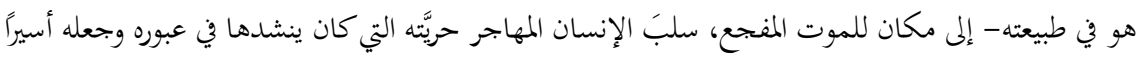

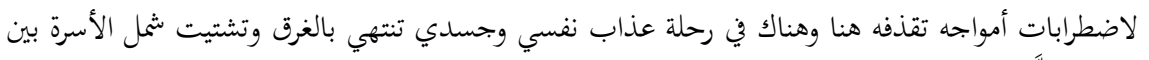
غريق ومحطّم الفؤاد على من فقدَّ.

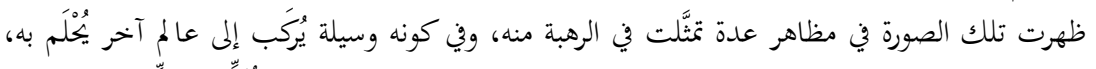

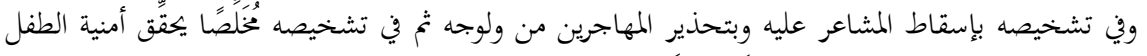

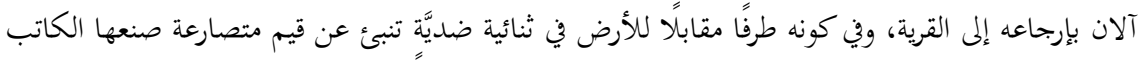
فكشفت ماكشفت من مساوئ البشر من جهة، وخير جميل من جهة أخرى.

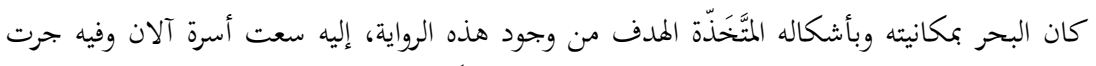

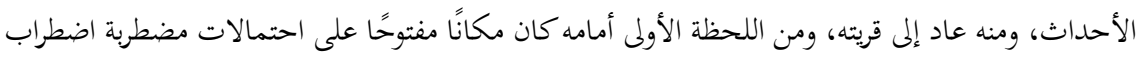

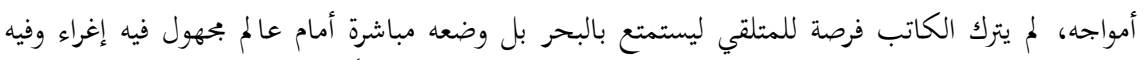

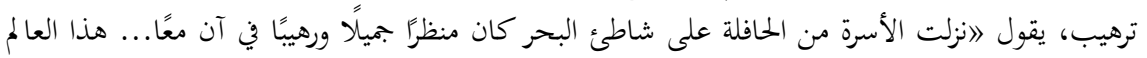


الرهيب الجميل، الذي يشعر القلب بشعورين كلاهما يبعث على الاضطراب؛ عالم ساحر يغريك بالنزول إليه،

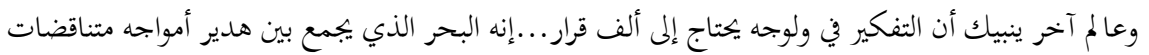

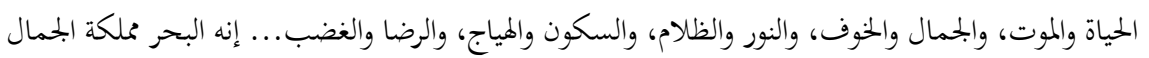
والخوف...23.

استحضرت أم آلان صورة البحر المخيف، وهي التي غيَّب الكاتب شخصيتها في بحمل الرواية وحين

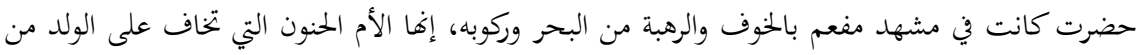

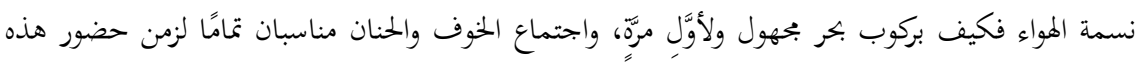

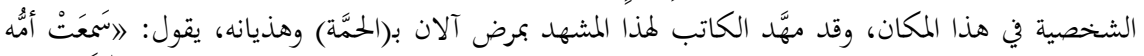

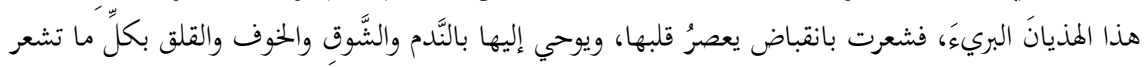

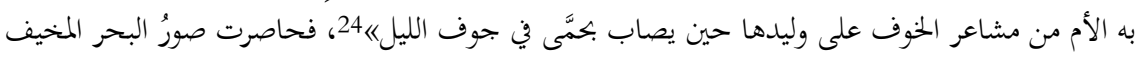

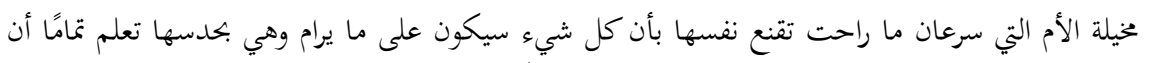

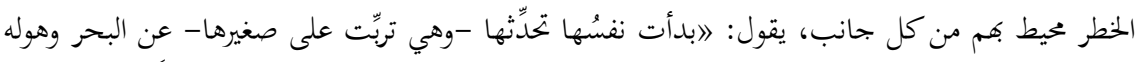

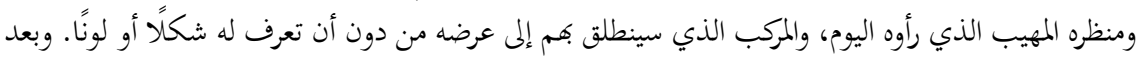

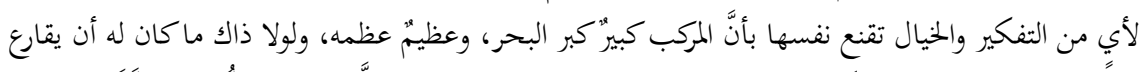

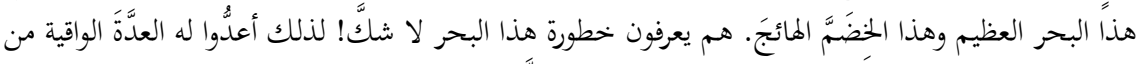

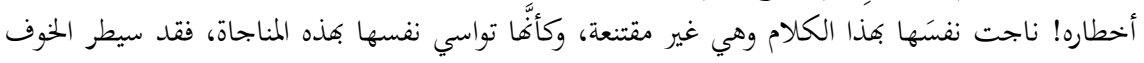

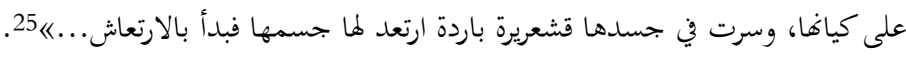

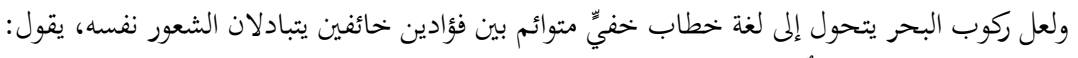

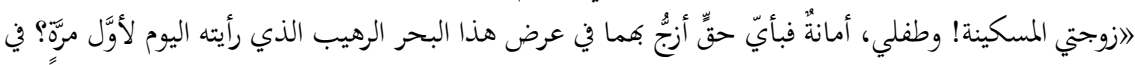

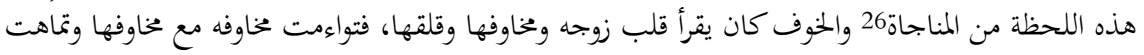

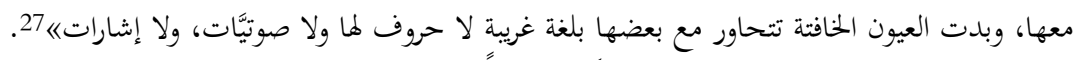

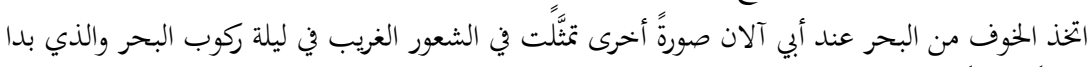

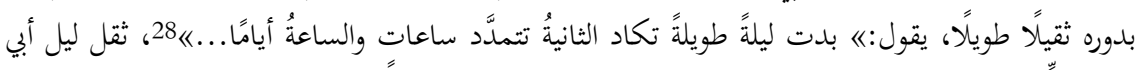

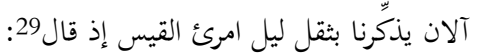

$$
\text { علوَيَّ بأنواع الهموم ليبتلي }
$$



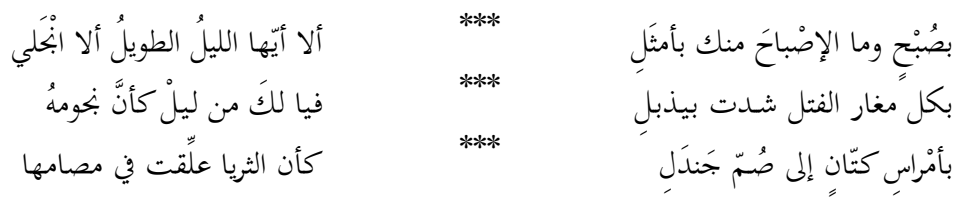

وصف الكاتب هذا الشعور بقوله: "بدأ قلب أبي آلان بالخفقان أكثرَ فأكثرَ، ينتابه شعور غريبٌ لا

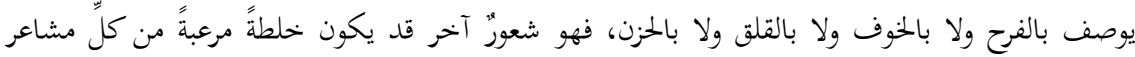

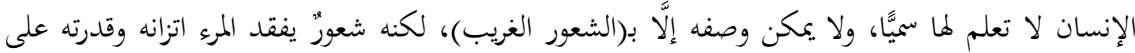

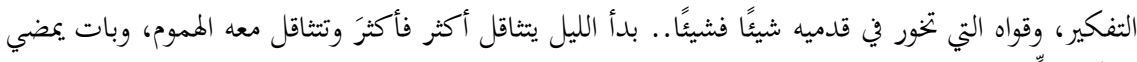

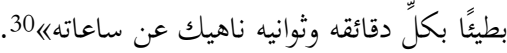

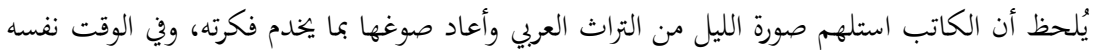

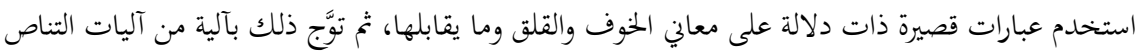

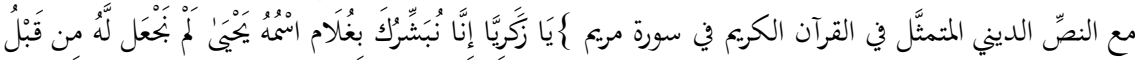

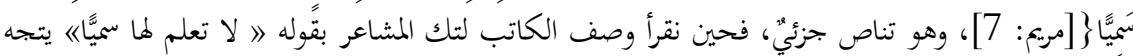

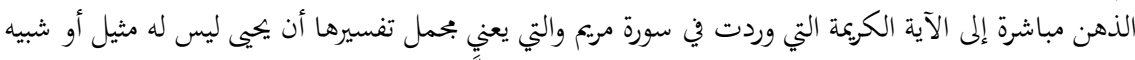

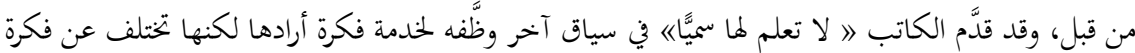

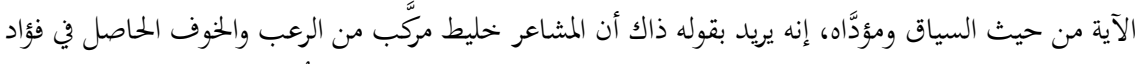

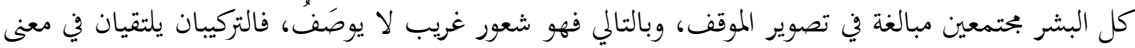

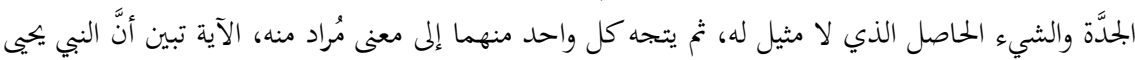

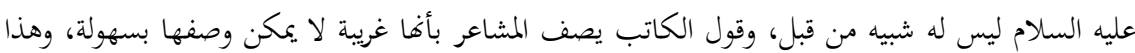

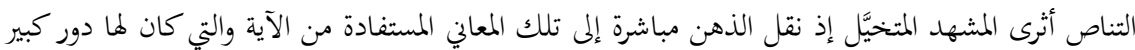

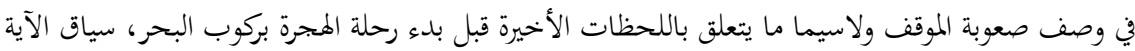

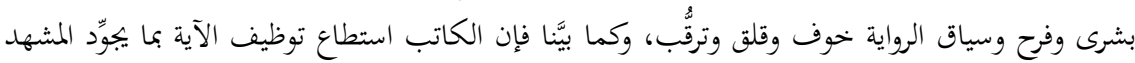

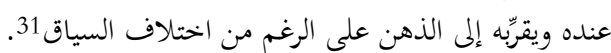
مأساة الأسرة دفعت الكاتب إلى بحاوز نقطة مكانية مهمة عادئ عادة، فالبحر وسيلة للهجرة إلى عالى عالم آخرافر

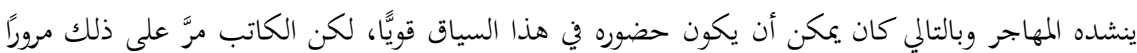

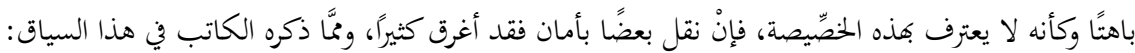

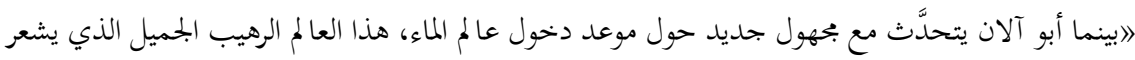

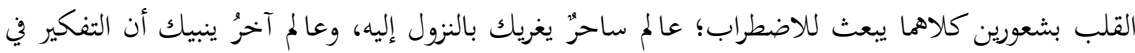

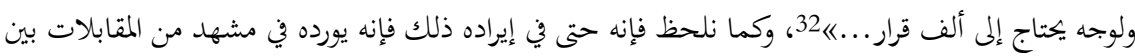
الإيجابي والسلبي في كل ما يمكن إسقاطه على المشهد. 
خلع الكاتب مشاعر المهاجرين الحزينة على البحر راميًا إياه بكل ثقل تلك المشاعر شخَّصه في مناسبات

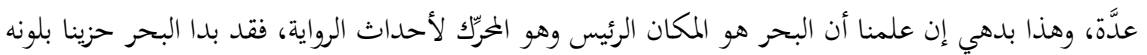

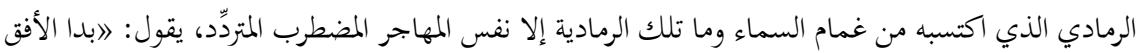

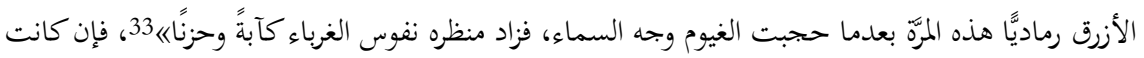

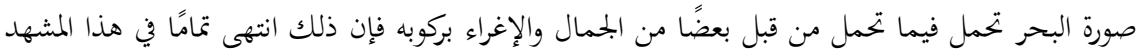

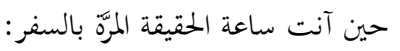

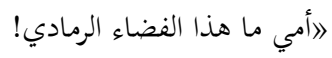

إنه البحر يا آلان. - مان.

البحر! ولكنَّ البحر الذي رأيناه كان أزرق فلماذا تغيَّ لونه اليوم؟ آلان

لأن السماء غائمة يا بنيَّان3.

وفضلًا عن مشاعر البحر التي تبعث الأسى في النفس فقد لجأ إلى تشخيصه حين استنطقه وأراده محذًِّا

من ولوجه، يقول:

》ا إياكم والدخول في مملكتي أيها الغرباء.

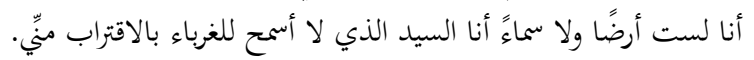

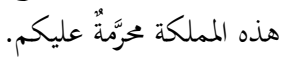

أنا الموت.

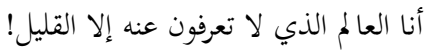

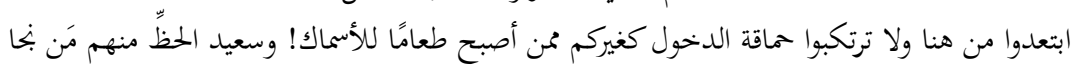

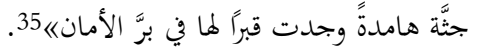

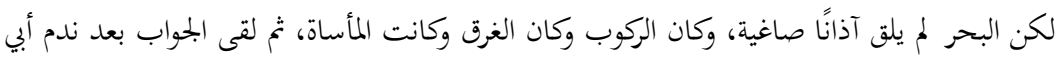

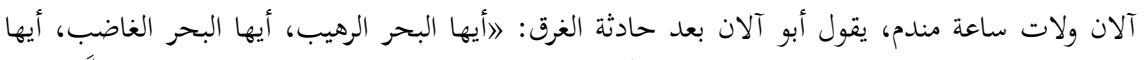

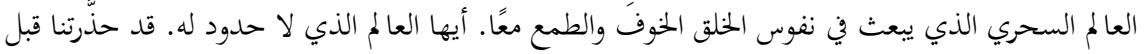

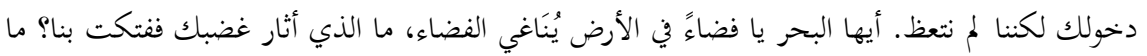

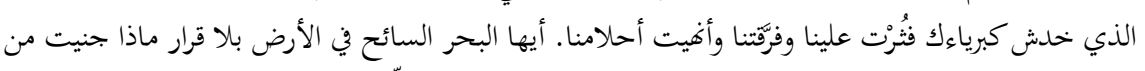

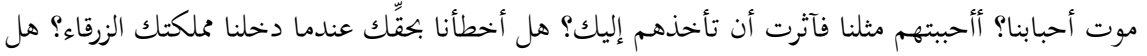

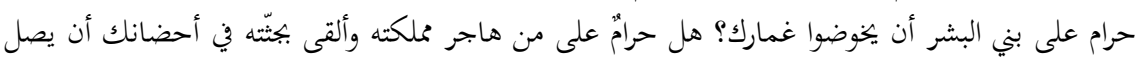

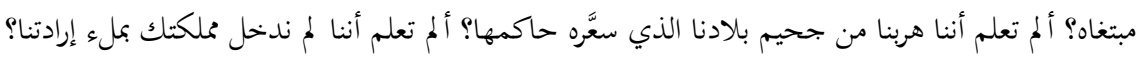

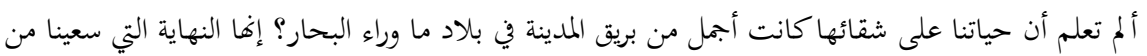

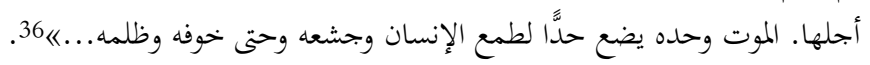


أراد الكاتب من آلان في الرواية طفلاً يتكلم ويستفسر ويشارك في أحداثها لغايات فنية جمالية، ومعلوم

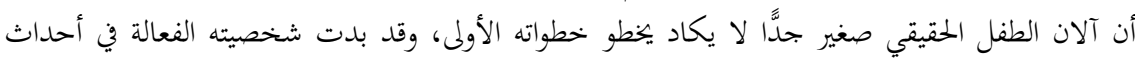

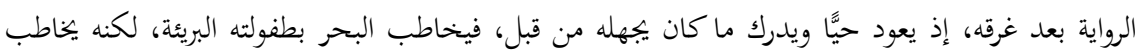

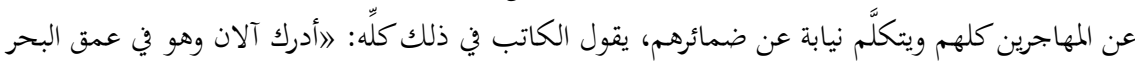

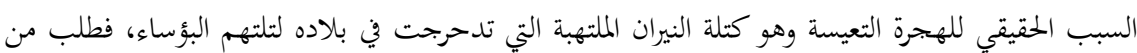

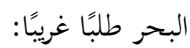

$$
\begin{gathered}
\text { أيها البحر أرجوك أن تنقذ قريتي وبلادي. } \\
\text { وكيف ذاك يا آلان؟ على رأس موجة من أمواجك العاتية. } \\
\text { آلماذا يا آلان؟ }
\end{gathered}
$$

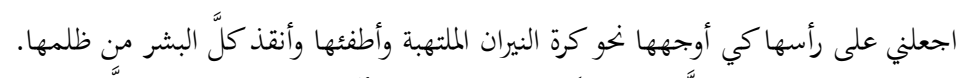

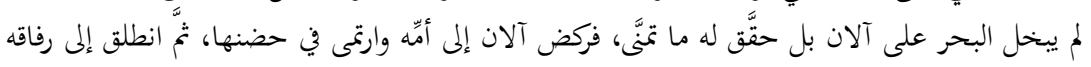

$$
\text { ليكمل لعبة كرة القدم، صاح الأطفال: }
$$

إذن ليس البحر وسيلة صادقة لتحقيق الأحلام، فهي تموت فيه، لكن مكان تحقيق الأحلام يكون في الوطن

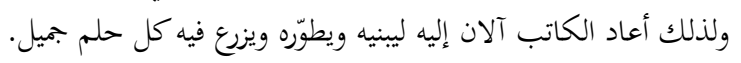

\section{الخاتمة والنتائج:}

(أحلام في البحر) رواية تكاد تكون قصة من ناحية الحجم أولى الكاتب فيها عناية كبيرة في تصوير البحر

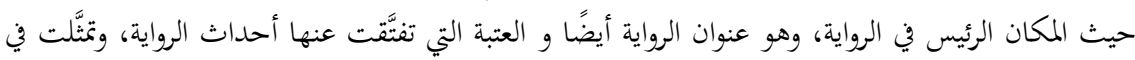

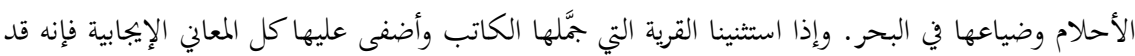

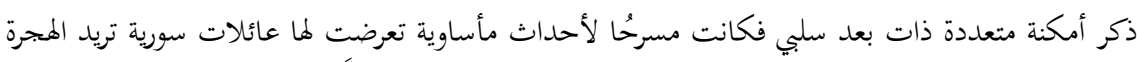

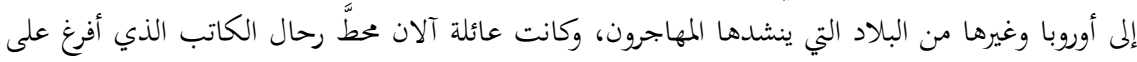

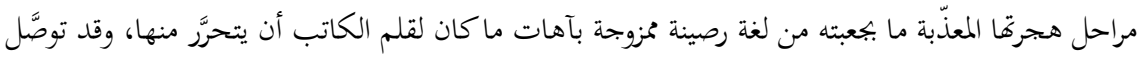

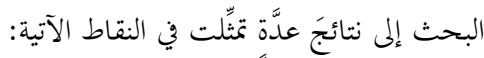

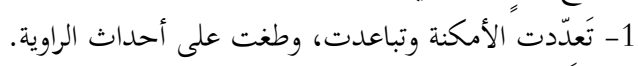

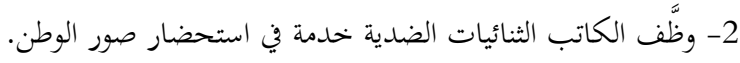

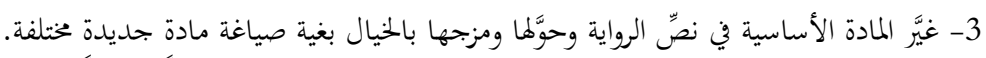

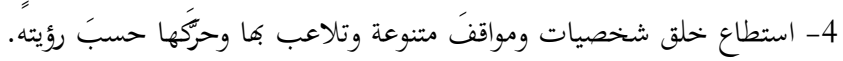

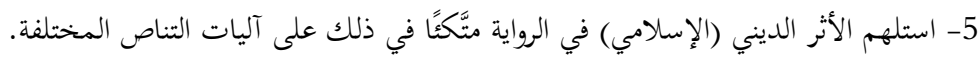


6- مزج الواقع بالخيال مما اضطره إلى تغيير بعضٍ من الأمور حتَّى يتسنى له ذلك (عُمر آلان .

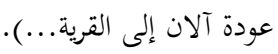

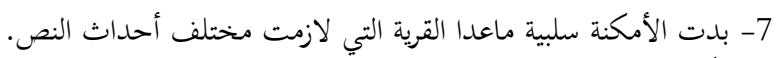

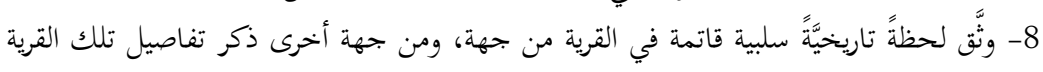
التي عبَّ من خلالها عن كل ماهو جميل في الوطن.

\section{المصادر والمراجع}

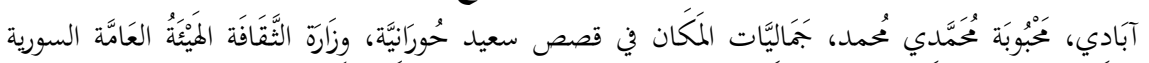
للكتاب، دمشق، 2011.

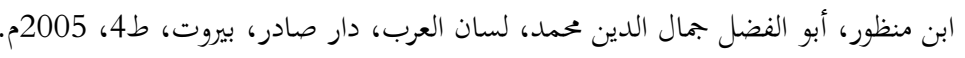

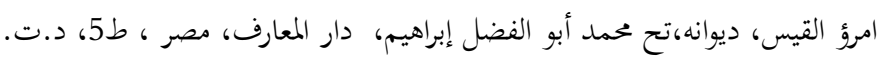

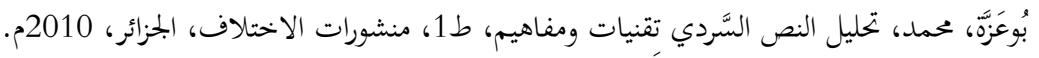

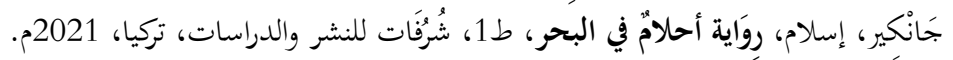

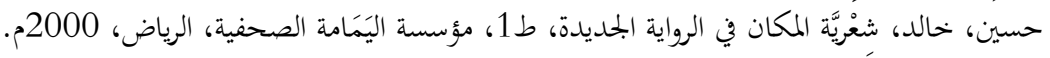

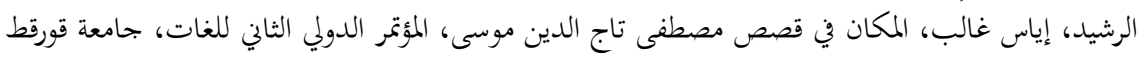

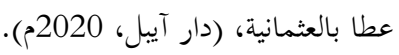

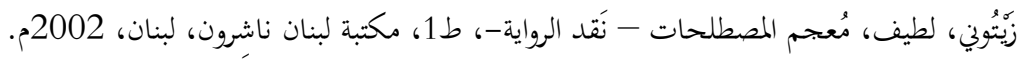

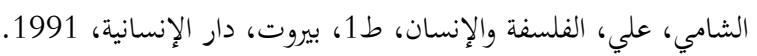

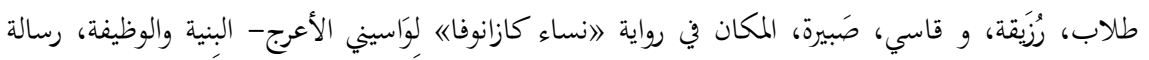

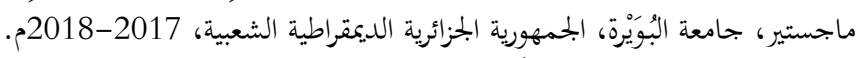

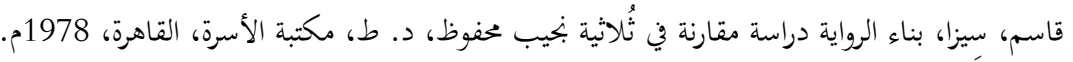

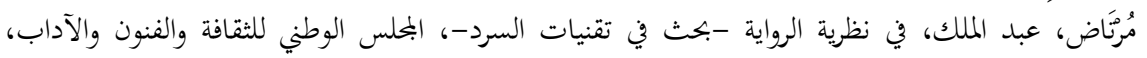
الكويت، 1998م.

\section{Kaynakça}

Abâdî, Mahbûba Muhammedî Muhammed. Cemâliyyâtu'l-Mekên fî Kısasi Sầd Hûrâniyye. Dımaşk: Vizêratu's-Sekâfeti'1-Hey'eti'l- 'Âmmeti’s-Sûriyye li'1Kuttâb, 2011.

Jânkîr, Aslam. Rivêyetu'l-Ehlâm fi'l-Bahr. Türkiye: Şürufât li’n-Neşri ve'd-Dirâsât, 1. Baskı, 2021.

Hüseyin, Hâlid. Şíriyyetül-Mekân fír-Rivâyeti'l-Cedîde. Riyad: Müessesetü'lYemâmeti's-Sahâfiyye, 1. Baskı, 2000.

Râşid, İyâs Gālip. “El-Mekân fî Kısası Mustafa Tacuddin Musa”. el-Mü'temeru'd- 
marifetname • Cilt: 8 - Sayı 2

Devliyyi’s-Sânî li’l-Lügât. Osmaniye: Câmiatu Korkut, Aybel Yayınc1lı, 2020.

Zeytûnî, Latîf. Mu'cemu'l-Mustalahât-Nakdu'r-Rivâye. Lübnân: Mektebetu Lübnân Nâşirûn, 1. Baskı. 2002.

Şâmî, Ali. el-Felsefetü ve'l-İnsân. Beyrût: Dâru'l-İnsâniyye, 1. Baskı, 1991.

Tullâb, Ruzeyka - Kasî, Sabîra. el-Mekân fî Rivâyeti "Nisầ Kazanova” li Vâsîynî el-A'rac-el-Binye va'l-Vazîfe. el-Cumhûriyyatu'l-Cezâiriyyetu'd-

Demoktrâtiyyetu'ş-Şa biyye: Câmiatu Buveyra, Risâletu Mâcistir, 20172018.

Bû̀azza, Muhammed, Tahlîlu’n-Nassis-Serdî Takniyyât ve'l-Mefâhim. Cezâyir: Menşûrâtu'l-İhtilêf, 1. Baskı, 2010.

Kâsım, Sîzâ. Binâu'r-Rivâyêt Dirâse Mukârane fi Sülâsiyyeti Necîb Mabfûz. Kâhire: Mektebetu'1-Üsra, 1978.

Murtâd, Abdülmelik. "Fî̀ Nazriyyeti'r-Rivâye-Bahsun fî̀ Takniyyâti's-Serd” elMeclisu'l-Vatanî li's-Sekâfe ve'I-Fünûn ve'l-ÊEêp. Kuveyt ,1998.

İbn Manzûr, Ebü'l-Fazl Cemâlüddîn Muhammed. Lisânül'-'Arab. Beyrut: Dâru'sSâdır, 4. Baskı, 2005. 